Cheng, M.-Y., Wibowo, L.S.B., Lequesne, R.D., and Lepage, A. (2016) Deformation Capacity and Strength of RC Frame Members with High-Strength Materials. In SP-311: James K. Wight: A Tribute from his Students and Colleagues. Farmington Hills, MI: American Concrete Institute.

\title{
Deformation Capacity and Strength of RC Frame Members with High-Strength Materials
}

\author{
Min-Yuan Cheng, Leonardus S. B. Wibowo, Remy D. Lequesne and Andres Lepage
}

Synopsis: Some implications of using high-strength concrete and steel materials in reinforced concrete frame members are discussed in terms of both flexural design and behavior. Through an example, it is demonstrated that the computed sectional curvature is highly sensitive to the choice of rectangular stress block used to model compression zone stresses of high-strength concrete. Comparison of various models suggests that the use of the stress block model defined in the ACI Building Code tends to overestimate curvature for concrete strengths exceeding $12 \mathrm{ksi}(83 \mathrm{MPa})$. In addition, recent test data are presented for flexure-dominated concrete members reinforced with high-strength steel bars. The effects of replacing Grade 60 (410) flexural reinforcement with Grade 100 (690) steel on deformation capacity, stiffness, and strength are examined. Test data support the viability of using Grade 100 (690) longitudinal reinforcement to resist loads that induce force-displacement response well into the nonlinear range.

Keywords: High-Strength Steel, High-Strength Concrete, Seismic, Earthquake, Flexure 
Min-Yuan Cheng, MACI, is an Associate Professor of Civil and Construction Engineering at National Taiwan University of Science and Technology in Taipei, Taiwan. He is a member of ACI Sub-Committee 318-J, Joints and Connections; Joint ACI-ASCE Committee 352, Joints and Connections in Monolithic Concrete Structures; and an associate member of ACI Committee 335, Composite and Hybrid Structures.

Leonardus S. B. Wibowo is a PhD Student of Civil and Construction Engineering at National Taiwan University of Science and Technology in Taipei, Taiwan. He received his BS degree in Civil Engineering from Universitas Brawijaya, Malang, Indonesia, and MS degree in Civil Engineering from Institut Teknologi Sepuluh Nopember, Surabaya, Indonesia.

Rémy D. Lequesne, MACI, is an Assistant Professor of Civil, Environmental and Architectural Engineering at the University of Kansas. He is Secretary of Joint ACI-ASCE Committee 408, Bond and Development of Steel Reinforcement; and a member of ACI Sub-Committee 318-J, Joints and Connections; and Joint ACI-ASCE Committee 352, Joints and Connections in Monolithic Concrete Structures. His interests include earthquakeresistant design and the behavior of reinforced concrete and fiber reinforced concrete members.

Andres Lepage, FACI, is an Associate Professor in the Department of Civil, Environmental, and Architectural Engineering at The University of Kansas, Lawrence, KS. He is a member of ACI Committees 335, Composite and Hybrid Structures; 374, Performance-Based Seismic Design of Concrete Buildings; 375, Performance-Based Design of Concrete Buildings for Wind Loads; and ACI Subcommittee 318-R, High-Strength Steel Reinforcement in Reinforced Concrete Design.

\section{INTRODUCTION}

In the United States, there is increasing interest in the use of high-strength materials in structures designed to resist extreme loading events (due to earthquake, wind, or blast). The term "high-strength" typically refers to concrete with a compressive strength greater than $8 \mathrm{ksi}(55 \mathrm{MPa})$ and steel reinforcement with a yield strength greater than $80 \mathrm{ksi}(550 \mathrm{MPa})$. Advantages of using these high-strength materials include smaller member sizes and reduced reinforcement congestion. High-strength concrete is already somewhat common in U.S. practice; particularly in tall structures where minimizing column dimensions is an important consideration. Use of highstrength steel has been far more limited in the United States. ${ }^{1,2}$. This disparity is a reflection of current ACI Building Code $^{3}$ provisions for earthquake-resistant design, which do not place an upper limit on the specified concrete compressive strength, $f_{c}^{\prime}$, but do limit the specified yield strength, $f_{y}$, to $60 \mathrm{ksi}$ (410 MPa) for primary longitudinal reinforcement.

The aim of this paper is to highlight unresolved issues pertaining to the behavior and design of flexural members constructed with high-strength materials. Potential limitations of ACI Building Code ${ }^{3}$ provisions for flexural design are discussed and future research needs are identified. Results from recent tests of beam specimens subjected to reversed cyclic loading are presented to show the effect of high-strength reinforcement on member behavior. Implications of using high-strength materials on the design of members for demands other than flexure, including serviceability and shear, are outside the scope.

\section{HIGH-STRENGTH CONCRETE FLEXURAL MEMBERS}

Research on the use of high-strength concrete has been extensively reviewed in ACI ITG4 4 . One issue that has been addressed is the validity of applying the equivalent rectangular compressive stress block defined in the ACI Building Code $^{3}$ or ACI stress block (illustrated in Fig. 1) to high-strength concrete, which exhibits a different relationship between stress and strain than normal strength concrete. As documented in ACI ITG4 ${ }^{4}$, most studies on this topic have focused on the calculated strength of columns because the nominal moment strength of beams is less sensitive to the shape of the assumed stress block. These studies have not evaluated whether the use of the ACI stress block results in a reasonable estimate of neutral axis depth. This is worth considering because the stress block was not originally intended for use in determining member deformability ${ }^{5,6}$. In current practice, the neutral axis depth calculated with the ACI stress block affects strength reduction factors for combined flexural and axial strength, moment redistribution in continuous flexural members, and prediction of member deformation capacity. 


\section{Comparison of Compression Zone Stress Block Definitions}

The computed sectional curvature associated with flexural strength (or nominal moment capacity) of reinforced concrete members cannot be directly obtained from traditional load-deflection measurements because strain measurements on concrete surfaces involve a gauge length, whereas sectional curvature does not. The question of whether deformations calculated using the ACI stress block are reasonable is therefore explored through comparison with results from other stress block models. As shown in Table 1, the definition of the equivalent stress block model has many variations depending on the design standards ${ }^{3,4,7-10}$. Several other equivalent stress block definitions (Table 2) have also been proposed ${ }^{11-16}$ with the aim of more accurately representing the force in the compression zone when using high-strength concrete. The models differ in several respects, including the limiting value of compressive strain $\left(\varepsilon_{c u}\right)$.

To illustrate the differences between the curvatures calculated using the equivalent stress block definitions shown in Tables 1 and 2, a rectangular reinforced concrete beam (Fig. 2) was analyzed. The beam has crosssectional dimensions of 16 by 28 in. (410 by $710 \mathrm{~mm}$ ) and is reinforced with 6 No. 10 (D32) longitudinal reinforcing bars (longitudinal reinforcement ratio of 2\%) that are assumed to have a yield strength of 60 ksi (410 $\mathrm{MPa}$ ) and elasto-plastic stress-strain behavior.

The nominal moment strength of the example beam was calculated for concrete compressive strengths ranging from 4 to $20 \mathrm{ksi}$ ( 28 to $138 \mathrm{MPa}$ ) using each of the stress block models shown in Tables 1 and 2. Figure 3 shows the flexural strengths calculated with the various models divided by the nominal strength $\left(M_{n}\right)$ calculated using the ACI stress block. As expected, the computed moment capacity is not sensitive to the stress block model. Calculated strengths differ by less than $5 \%$ for concrete compressive strengths ranging from 4 to $20 \mathrm{ksi}$ (28 to 138 $\mathrm{MPa})$.

The sectional curvature associated with the nominal flexural strength was also calculated for the example beam using each stress block model. The calculated sectional curvature, divided by that calculated using the ACI stress block, is plotted in Fig. 4 for concrete compressive strengths ranging from 4 to $20 \mathrm{ksi}$ (28 to $138 \mathrm{MPa}$ ). The calculated sectional curvatures differ from that calculated using the ACI stress block by as much as $60 \%$. Among the models, use of the Eurocode $2^{8}$ stress block led to the largest calculated curvature and the stress block proposed by Bae and Bayrak ${ }^{12}$ resulted in the smallest.

The computed curvature ratios in Fig. 4 suggests that for concrete strengths not exceeding 9 ksi (62 MPa), the rectangular stress block of the ACI Building Code $^{3}$ leads to smaller curvatures when compared to curvatures obtained from the use of stress blocks by others. For concrete strengths exceeding 9 ksi, the wide variations in computed curvature ratios suggest that the stress block of the ACI Building Code ${ }^{3}$ should be reexamined considering the data supporting the definition of other stress block models.

\section{HIGH-STRENGTH STEEL REINFORCED FLEXURAL MEMBERS}

The limits on the specified yield strength of reinforcing bars in the ACI Building Code $^{3}$ trace back to its 1963 edition ${ }^{17}$ and are primarily related to the prescribed limit of the compressive strain to 0.003 for concrete and to control crack width at service load ${ }^{18}$. The latest version of the ACI Building Code ${ }^{3}$ prescribes a maximum specified yield strength of $60 \mathrm{ksi}(410 \mathrm{MPa})$ to resist shear and torsion forces, $80 \mathrm{ksi}(550 \mathrm{MPa})$ to resist flexure and axial forces, and $100 \mathrm{ksi}(690 \mathrm{MPa})$ for confining reinforcement. For earthquake-resistant structures, where yielding of reinforcement is likely to occur, the ACI Building $\mathrm{Code}^{3}$ reduces the maximum specified yield strength of $80 \mathrm{ksi}$ to $60 \mathrm{ksi}(410 \mathrm{MPa})$ and maintains the limit of $100 \mathrm{ksi}(690 \mathrm{MPa})$ for confining reinforcement.

The ACI Building Code ${ }^{3}$ requires that Grade 60 (410) reinforcement used in earthquake-resistant structures (particularly those classified as "special" structural systems) satisfy the following criteria: 1) actual yield strength based on mill tests does not exceed $78 \mathrm{ksi}(540 \mathrm{MPa})$; 2) tensile-to-yield strength ratio is at least 1.25, and 3) fracture elongation, $\varepsilon_{\text {su }}$, measured in an 8 -in. $(203 \mathrm{~mm}$ ) gauge length is at least $14 \%$ for No. 6 (D19) and smaller bars, $12 \%$ for No. 7 through No. 11 bars (D22 and D36), and 10\% for larger bars. Grade 60 (410) reinforcement is not required to exhibit a sharp yield point, but such a yield point is typically observed with a plateau followed by strain hardening. 
In the United States there are no design standards defining required mechanical properties for high-strength steel reinforcement to be used as primary reinforcement in earthquake-resistant structures. This is despite an increasing number of studies ${ }^{1,2,20-22}$ demonstrating the potential benefits of high-strength steel. Efforts ${ }^{20}$ to promote a new standard have led to questions about which attributes are critical to performance. In Japan, the new RC project ${ }^{23}$ led to the acceptance of Grade $100(690)$ steel exhibiting a: 1$)$ tensile-to-yield strength ratio $\left(f_{u} / f_{y}\right)$ greater than $1 / 0.85,2) \varepsilon_{s u}$ of at least $10 \%$, and 3) a distinct yield plateau. It is, however, difficult to produce such reinforcement in the United States without major adjustments to current steel production practices. The influence of these properties has been partially investigated analytically ${ }^{20}$, but the results are very sensitive to modeling assumptions. Experimental evidence is needed to help define the acceptable range of values for key mechanical properties.

Tests of specimens constructed with high-strength steel reinforcement

Results from laboratory tests of RC beams reinforced with different types of high-strength longitudinal reinforcement and subjected to reversed cyclic loads have been recently reported by Cheng and Giduquio ${ }^{22}$ and Tavallali et $\mathrm{al}^{1}$. The test data illustrate the influence of various reinforcement attributes on specimen response.

Description of tests and materials - Details of the test specimens and experimental setups are presented in Fig. 5 and Fig. 6, respectively. Cheng and Giduquio ${ }^{22}$ tested three beam specimens: Specimen SP1 was reinforced with conventional Grade 60 (410) longitudinal reinforcement, and Specimens SP2 and SP3 were reinforced with Grade 100 (690) longitudinal reinforcement. The mechanical properties of the reinforcing bars in Specimen SP2 comply with the Japanese SD685 Standard ${ }^{23}$, whereas those in Specimen SP3 comply with the ASTM A1035 Standard ${ }^{24}$. The Cheng and Giduquio specimens had a nominal concrete compressive strength of $5 \mathrm{ksi}(35 \mathrm{MPa})$. The Tavallali et al. ${ }^{1}$ specimens had a nominal concrete compressive strength of $6 \mathrm{ksi}(41 \mathrm{MPa})$. Of the seven specimens tested by Tavallali et al., two specimens will be considered herein: Specimen CC4-X, which was reinforced with conventional Grade 60 (410) longitudinal reinforcement, and Specimen UC4-X, which was reinforced with Grade 97 (670) longitudinal reinforcement in compliance with ICC-ES ${ }^{25}$. Within each group of specimens, identical flexural strength was targeted and therefore the area of tensile reinforcement provided was nearly inversely proportional to the reinforcement yield strength (i.e., $\rho f_{y}$ was approximately constant, where $\rho$ is the longitudinal reinforcement ratio). All specimens were designed to have a shear capacity greater than the shear demand associated with the probable flexural strength determined for a flexural reinforcement stress of 1.25 times the specified yield strength of the flexural reinforcement. The longitudinal reinforcement in the beams tested by Cheng and Giduquio ${ }^{22}$ was anchored using 90-degree hooks beyond the critical sections and into the top and bottom blocks (see Fig. 6(a)). In the beams tested by Tavallali et $\mathrm{al}^{1}$, the reinforcement was straight and continuous through the 16-in (41-mm) column stub (see Fig. 6(b)).

Minimum required tensile-test properties for the high-strength steels used in these studies are listed in Table 3. Curves representing the stress-strain relationships exhibited by these steels in direct tensile tests are plotted in Fig. 7. As shown, ASTM A1035 high-strength steel exhibited a so-called "roundhouse" stress-strain curve with no sudden change in slope associated with yielding. In contrast, the high-strength steel classified as SD685 exhibited a distinct yield plateau, whereas the Grade 97 (670) steel exhibited a distinct yield point followed by a nearly constant post-yield slope. A summary of measured mechanical properties from tensile tests of the steels used in the two studies is given in Table 4.

Both series of specimens were subjected to reversed cyclic displacement demands of increasing magnitude, with either two or three cycles imposed at each target displacement. The Cheng and Giduquio specimens were subjected to three cycles at each displacement increment for chord rotations up to $2 \%$, and two cycles thereafter. The Tavallali et al. specimens were subjected to two cycles at each target displacement throughout the test. For more information, see References 1 and 22.

General test results - Table 5 presents a summary of the test results, including the ultimate deformation capacity, $d_{u}$, which was defined as the average of the maximum chord rotation reached in each loading direction prior to a $20 \%$ strength drop from the peak. The response of the five specimens is shown in Fig. 8 for the moment calculated at the face of the joint versus chord rotation. Chord rotation is defined as the displacement (between points of zero and maximum moments) divided by the span length and corrected for rotation of either the concrete base block or column stub, depending on the test setup. A line segment is also shown in Fig. 8 to illustrate the effective initial 
stiffness. This line segment connect the origin to the effective yield point, which was defined as the point where a horizontal line drawn at $0.9 M_{n, e}$ first intersects the hysteretic curve. The expected flexural strength, $M_{n, e}$, is calculated using measured material strengths $\left(f_{c}^{\prime}\right.$ and $\left.f_{y}\right)$, the ACI stress block for concrete, and elasto-plastic stressstrain behavior for steel.

As shown in Fig. 8, the specimens reinforced with high-strength reinforcement exhibited a response to imposed deformations that was similar to the control Grade 60 (410) specimens except for having slightly narrower hysteretic loops. The deformation capacities were similar, as were the observed flexural strengths. It can also be observed that the envelope of the hysteretic response has a shape similar to the constitutive relationship of the flexural reinforcement. For example, the curve plotted in Fig. 8c has a roundhouse shape similar to ASTM A1035 reinforcement, whereas the other curves have a clear change in slope associated with yielding.

Deformation Capacity - The deformation capacity of Specimen SP1 was limited to a chord rotation of $4.7 \%$ by buckling of the longitudinal bars. This specimen was constructed with Grade 60 (410) reinforcement and confined by No. 3 hoops spaced at $5.7 d_{b}$, where $d_{b}$ is the diameter of the corner longitudinal bars. Both Specimens SP2 and SP3, reinforced with Grade 100 (690) longitudinal reinforcement, failed at a chord rotation of $4.0 \%$ due to fracture of longitudinal reinforcement that was likely preceded by reinforcement buckling in the previous cycle. It is important to note that because the hoop spacing $(5 \mathrm{in}$. or $127 \mathrm{~mm}$ ) was the same in Specimens SP1, SP2, and SP3, the smaller longitudinal bars used in Specimens SP2 and SP3 were confined by hoops spaced at $8.0 d_{b}$, approximately twice the spacing recommended in NIST GCR 14-917-30 ${ }^{20}$ (2014) for Grade 100 (690) reinforcement. Both Specimens CC4-X and UC4-X, which had transverse reinforcement spaced at $2.3 d_{b}$ and $2.7 d_{b}$, respectively, sustained reversed cyclic loading up to a chord rotation of $5.0 \%$ without showing significant distress. Both specimens were subsequently subjected to a monotonic push to failure, and exhibited longitudinal reinforcing bar fracture at a chord rotation exceeding $15 \%$.

The limited test data presented in Table 4 and Figure 8 suggests that for beams to accommodate chord rotations of $4 \%$, high-strength steel bars should have $\varepsilon_{s u}$ of at least $6 \%$ and hoop spacing not greater than $8.0 d_{b}$, where $d_{b}$ is the bar diameter of longitudinal bars. The test data also suggests that chord rotations of $5 \%$ are attainable when using high-strength steel with $\varepsilon_{s u}$ of at least $10 \%$ and with closely spaced hoops to prevent bar buckling.

Spread of plasticity - The commentary of the ACI Building $\operatorname{Code}^{3}$ indicates that a higher $f_{u} / f_{y}$ leads to a wider spread of plastic deformations in a beam hinging region. The specimens tested by Cheng and Giduquio ${ }^{22}$ and Tavallali et al. ${ }^{1}$ included reinforcement with $f_{u} / f_{y}$ values between 1.21 and 1.56 (Table 4 ).

Test data from these specimens are examined to evaluate the effect of $f_{u} / f_{y}$ on the distribution of plasticity. The strain gauge data shown in Fig. 9 correspond to readings at a distance approximately equal to the effective depth, $d$, from the critical section. For Specimens SP1, SP2 and SP3, strain gauge readings are presented for chord rotations up to 3.0\%. The gauges in Specimens SP1, SP2 and SP3 show that strains in longitudinal reinforcement exceeded the reinforcement yield strain (estimated from direct tensile tests of coupons) at $d$ from the critical section. For SD685 and A1035 steel bars, the measured yield strain was $0.44 \%$ and $0.64 \%$ (based on the $0.2 \%$ offset method), respectively. Regarding Specimens CC4-X and UC4-X, Fig. 9(b) shows that during cycles of 3\% chord rotation, yielding occurred at a distance $d$ away from the critical section. However, this observation is inherently limited because strain gauge readings are highly sensitive to crack locations. Analysis of measured deformations ${ }^{22}$, not presented here, indicates that Specimens SP2 and SP3 exhibited similar curvature distribution. Additional research is necessary to evaluate reinforcements with lower $f_{u, \text { test }} / f_{y \text {, test }}$ as well as to better define the relationship between $f_{u, \text { test }} / f_{y, \text { test }}$ and the spread of plastic deformations.

Figure 9 also illustrates that the yield plateau had a negligible impact on member deformation. This is particularly clear in the plot of data from Specimens SP1 and CC4-X, where yielding caused a significant increase in strain without a proportional increase in chord rotation.

Stiffness - The slope of the initial segment shown in Fig. 8 is assumed to represent the cracked stiffness of the specimens, referred to as $K_{1}$. The $K_{1}$ calculated for each specimen was normalized by $K_{1,60}$, the cracked stiffness calculated for the control specimen in each set. In Fig. 10, $K_{1} / K_{1,60}$ is plotted versus the normalized flexural 
reinforcement ratio $\rho / \rho_{, 60}$, where $\rho_{, 60}$ is the reinforcement ratio for the Grade 60 (410) control specimen. As shown, the cracked stiffness is approximately proportional to the normalized flexural reinforcement ratio.

Figure 10 shows that for a given concrete beam reinforced with Grade 60 (410) steel bars, replacing the Grade 60 (410) reinforcement with reduced amount of high-strength reinforcement leads to a reduction in the beam initial stiffness. The reduction in stiffness is nearly proportional to the reduction in reinforcement ratio. Thus, beams reinforced for a target flexural strength (or $\rho f_{y}$ ) will have reduced stiffness $K_{l}$ in proportion to an increase in $f_{y}$.

Flexural strength - The ratio of flexural strength, $M_{\text {peak }}$, to the expected strength, $M_{n, e}$, of all test specimens is presented in Table 5, where $M_{n, e}$ is calculated using the ACI stress block, elastic-plastic steel properties, and the yield stress measured with tensile tests of coupons. For all test specimens, $M_{\text {peak }} / M_{n, e}<1.25$ even though

$f_{u, \text { test }} / f_{y, \text { test }}$ values for the reinforcement were as high as 1.56 . However, use of the measured yield stress instead of the nominal yield stress obscures the fact that high strength reinforcing steels can have significant overstrength. Therefore it may be appropriate to consider reinforcement overstrength, represented here by $R_{y}=f_{y, \text { test }} / f_{y, \text { specified }}$, when determining the probable moment capacity of flexural members ( $M_{p r}$ could be defined as $1.2 R_{y} f_{y}$ ). Alternatively, it may be necessary to limit $R_{y}$ and $f_{u} / f_{y}$ for reinforcing steel used in earthquake-resistant members.

\section{CONCLUDING REMARKS}

Based on the flexural strength and deformation characteristics presented for reinforced concrete beams with high-strength materials, the following general observations are drawn:

1. For concrete compressive strengths not exceeding $9 \mathrm{ksi}(62 \mathrm{MPa})$, computed sectional curvatures based on the use of the ACI Building Code are consistently smaller than those computed using stress block models proposed by selected researchers and design standards from Japan, New Zealand, and Europe. However, there are no consistent trends in computed curvatures for concrete strengths exceeding $9 \mathrm{ksi}$, an indication that the definition of the stress block model for high-strength concrete lacks general consensus.

2. Concrete beam specimens with shear span-to-depth ratio between 2 and 4 , and reinforced using steel bars with a specified yield strength between $60 \mathrm{ksi}(410 \mathrm{MPa})$ and $100 \mathrm{ksi}(690 \mathrm{MPa})$ and a total fracture elongation exceeding $6 \%$, exhibited stable hysteretic response to imposed chord rotations of $4 \%$.

3. The flexural strength of the high-strength steel-reinforced beam specimens of this study can be reasonably predicted using standard assumptions involved in calculating nominal flexural strength of beams with Grade 60 (410) reinforcement.

4. Strains consistent with yielding were measured in flexural reinforcement at a distance $d$ (effective depth) from the support face in all specimens, which included tensile-to-yield strength ratio $\left(f_{u} / f_{y}\right)$ between 1.2 and 1.6.

5. The limited test results indicate that the cracked stiffness of the specimens is nearly proportional to the tensile flexural reinforcement ratio $(\rho)$. The cracked stiffness of beams reinforced to attain the same flexural strength (with constant $\rho f_{y}$ ) had reduced cracked stiffness in proportion to the increase in the specified yield strength of reinforcement $\left(f_{y}\right)$.

\section{REFERENCES}

1) Tavallali, H.; Lepage, A.; Rautenberg, J. M. and Pujol, S., "Concrete Beams Reinforced with High-Strength Steel Subjected to Displacement Reversals," ACI Structural Journal, V. 111, No. 5, 2014, pp. 1037-1048.

2) Rautenberg, J., Pujol, S., Tavallali, H., and Lepage, A., "Reconsidering the Use of High-Strength Reinforcement in Concrete Columns," Engineering Structures, Elsevier, V. 37, 2012, pp. 135-142.

3) ACI Committee 318, "Building Code Requirements for Structural Concrete (ACI 318-14) and Commentary," American Concrete Institute, Farmington Hills, Michigan, 2014, 519 pp.

4) ACI Innovation Task Group 4 and Other Contributors, "Report on Structural Design and Detailing for HighStrength Concrete in Moderate to High Seismic Applications (ACI ITG-4.3 R-07)," American Concrete Institute, Farmington Hills, Michigan, 2008, 62 pp. 
5) Whitney, C. S., "Design of Reinforced Concrete Members under Flexure or Combined Flexural and Direct Compression," Journal of the American Concrete Institute, Proceedings Vol. 33, No. 3, March, 1937, pp. 483-498.

6) Hognestad, E.; Hanson, N. W.; and McHenry D., "Concrete Stress Distribution in Ultimate Strength Design," Journal of the American Concrete Institute, Proceedings Vol. 52, No. 12, 1955, pp. 455-479.

7) CAN-A23.3-04 "Design of Concrete Structures," Canadian Standards Association, Toronto, Canada, 2004, $232 \mathrm{pp}$.

8) European Committee For Standardization, "Eurocode2 : Design of concrete structures - Part 1-1 : General rules and rules for buildings," CEN, Brussels, 2004, 225 pp.

9) JSCE Concrete Committee, "Standard Specifications for Concrete Structures - 2007," Japan Society of Civil Engineers, Tokyo, Japan, 2010, 469 pp.

10) NZS 3101:Part 1:2006, "Concrete Structures Standard Part 1 - The Design of Concrete Structures," Standards Council, Wellington, New Zealand, 2006, 306 pp.

11) Azizinamini, A.; Kuska, S. S. B.; Brungardt, P.; and Hatfield, E., "Seismic Behavior of Square High-Strength Concrete Columns," ACI Structural Journal, Vol. 91, No. 3, 1994, pp. 336-345.

12) Bae, S. and Bayrak, O., "Stress Block Parameters for High-Strength Concrete Members," ACI Structural Journal, Vol. 100, No. 5, 2003, pp. 626-636.

13) Ibrahim, H. H. H. and MacGregor, J. G., "Modification of the ACI Rectangular Stress Block for HighStrength Concrete," ACI Structural Journal, Vol. 94, No. 1, 1997, pp. 40-48.

14) Khadiranaikar, R. B. and Awati, M. M., "Concrete Stress Distribution Factors for High-Performance Concrete," Journal of Structural Engineering, Vol. 138, No. 3, 2012, pp. 402-415.

15) Mertol, H. C.; Rizkalla, S.; Zia, P.; and Mirmiran, A., "Characteristics of Compressive Stress Distribution in High-Strength Concrete," ACI Structural Journal, Vol. 105, No. 5, 2008, pp. 626-633.

16) Ozbakkaloglu, T. and Saatcioglu, M., "Rectangular Stress Block for High-Strength Concrete," ACI Structural Journal, Vol. 101, No. 4, 2004, pp. 475-483.

17) ACI Committee 318, "Building Code Requirements for Structural Concrete (ACI 318-63) and Commentary," American Concrete Institute, Detroit, Michigan, 1963, 144 pp.

18) Lepage, A.; Tavallali, H.; Pujol, S.; and Rautenberg, J., "Towards Earthquake-Resistant Concrete Structures with Ultra High-Strength Steel Reinforcement," The 14th World Conference on Earthquake Engineering, Beijing, China, 2008, 8 pp.

19) Mast, R. F.; Dawood, M.; Rizkalla, S. H.; and Zia, P., "Flexural Strength Design of Concrete Beams Reinforced with High Strength Steel Bars," ACI Structural Journal, V. 105, No. 5, 2008, pp. 570-577.

20) NIST GCR 14-917-30, "Use of High-Strength Reinforcement in Earthquake-Resistant Concrete Structures," NEHRP Consultant Joint Venture, California, 2014, 231 pp.

21) Shahrooz, B. M.; Miller, R. A.; Harries, K. A.; and Russell, H. G., "Design of Concrete Structures Using High-Strength Steel Reinforcement," NCHRP Report 679, Transportation Research Board, Washington D. C., 2011, 72 pp.

22) Cheng, M-Y and Giduquio, M. B., "Cyclic Behavior of Reinforced Concrete Flexural Members Using HighStrength Flexural Reinforcement," ACI Structural Journal, V.111, No.4, 2014, pp. 893-902.

23) Aoyama, H., "Design of Modern High-rise Reinforced Concrete Structures", Series of Innovation in Structures and Construction, Imperial College Press, London, Vol. 3, 2001, 460 pp.

24) ASTM A1035, "Standard Specification for Deformed and Plain, Low-Carbon, Chromium, Steel Bars for Concrete Reinforcement," ASTM International, West Conshohocken, Pennsylvania, 2007, 5 pp.

25) ICC-ES, "Acceptance Criteria for Threaded High-Strength Steel Bars for Concrete Reinforcement (AC 237)," ICC Evaluation Report, ICC Evaluation Service, LLC., Brea, California, 2009, 6 pp. 


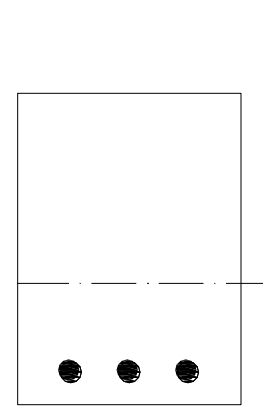

Beam Section
Equivalent

Stress Block

$\overline{\text { Neutral Axis }}$ $\alpha_{1}=$ ratio between the stress of the rectangular block and the maximum stress

$\beta_{1}=$ factor relating depth of equivalent rectangular compressive stress block to neutral axis depth

Fig. 1 - Equivalent Stress Block Based on ACI Building Code ${ }^{3}$

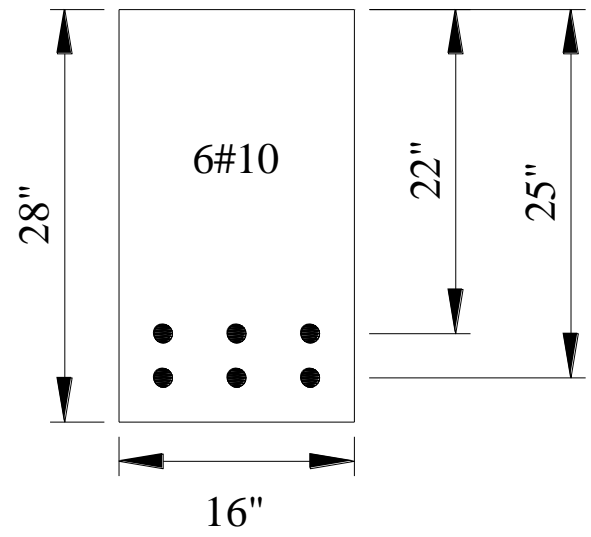

$$
f_{c}^{\prime}=4-20 \mathrm{ksi}(28-138 \mathrm{MPa})
$$

Fig. 2 - Cross Section for Analysis (1 in. = $25.4 \mathrm{~mm}$ ) 


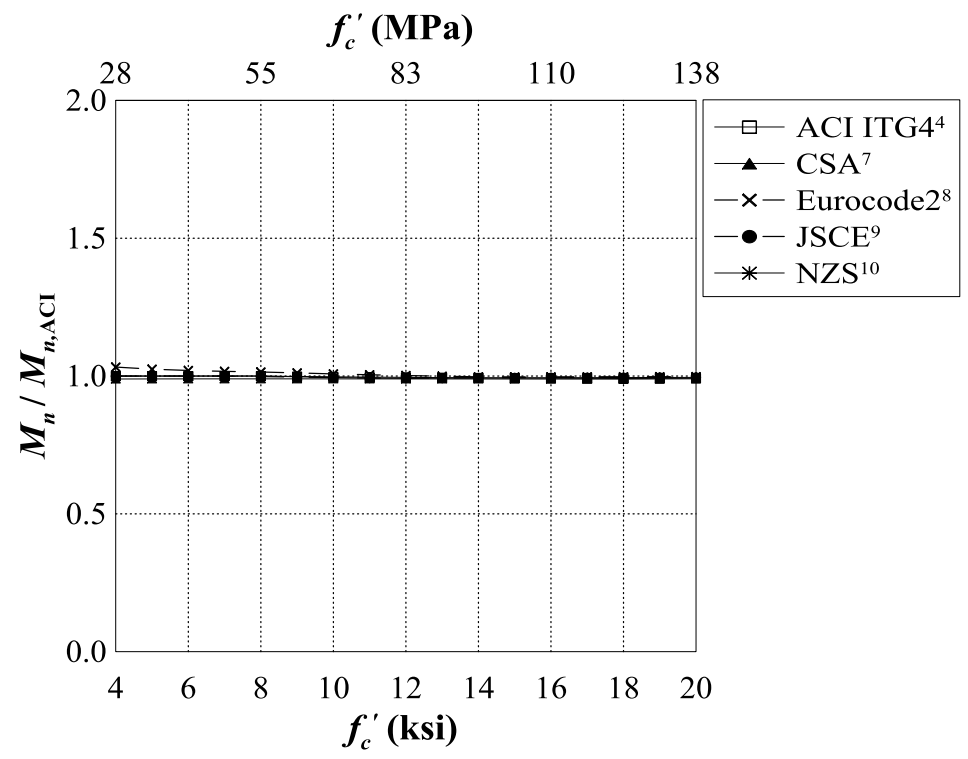

(a) Stress Block Models in Committee Reports and Building Codes

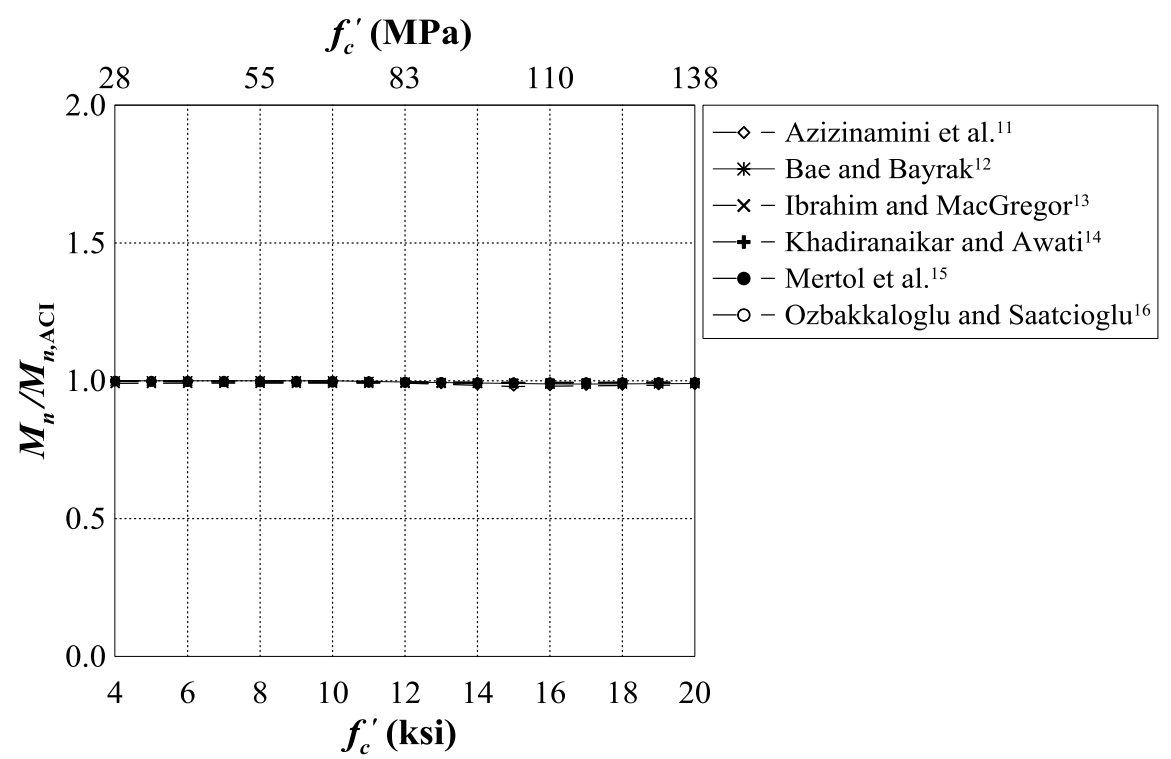

(b) Stress Block Models Proposed by Researchers

Fig. 3 - Computed Moment Ratios 


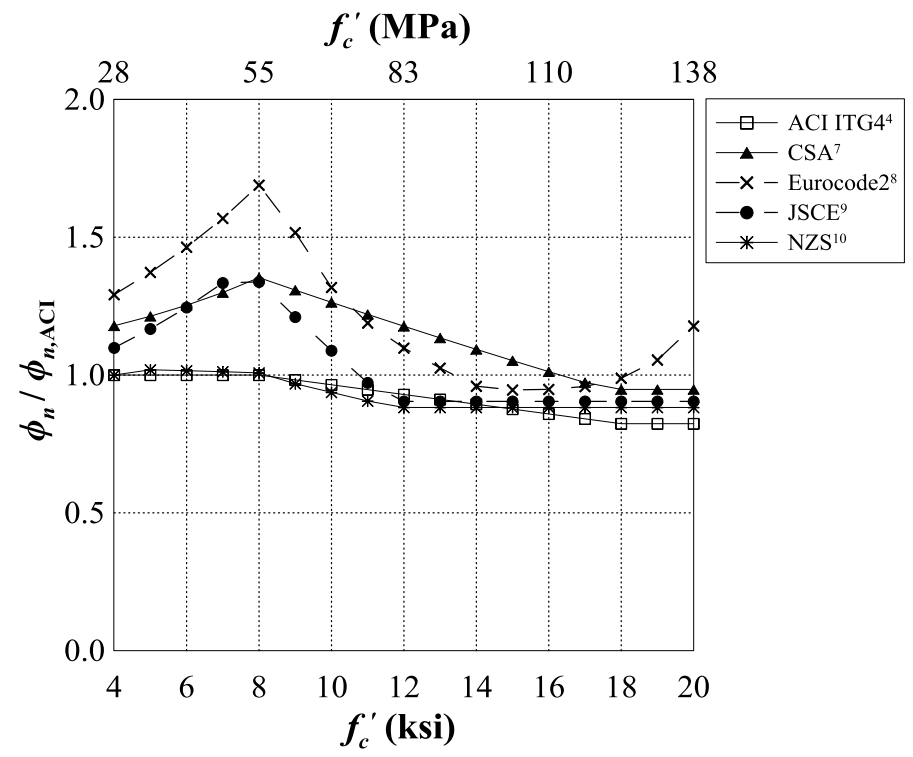

(a) Stress Block Models in Committee Reports and Building Codes

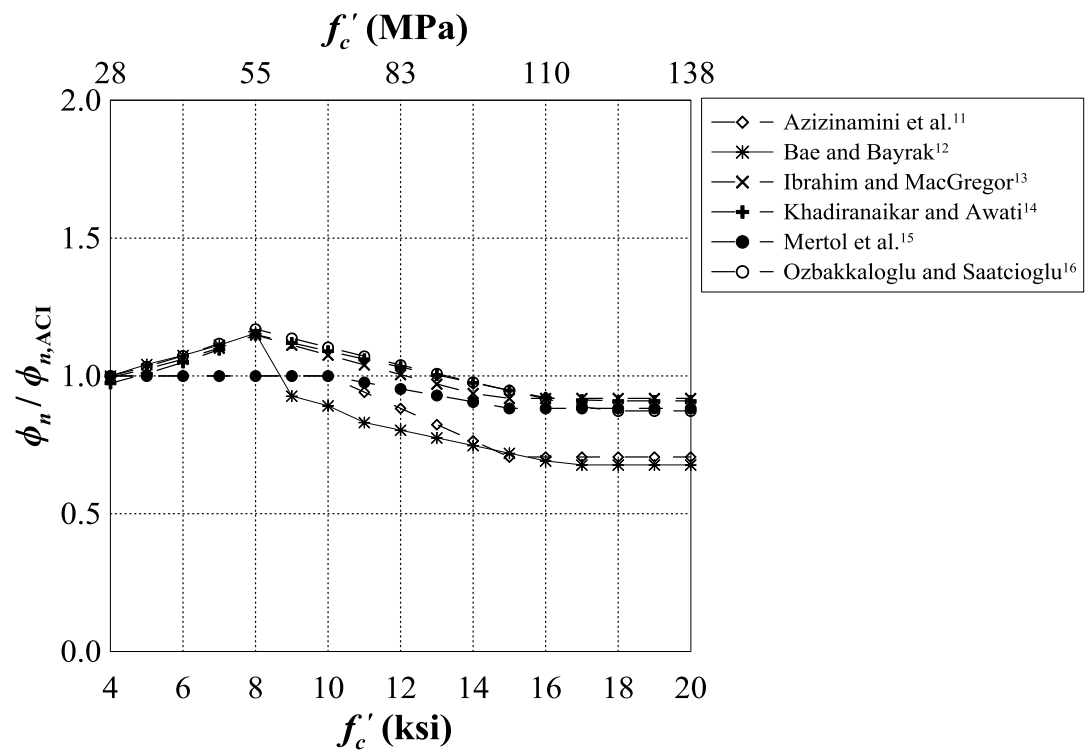

(b) Stress Block Models Proposed by Researchers

Fig. 4 - Computed Curvature Ratios 


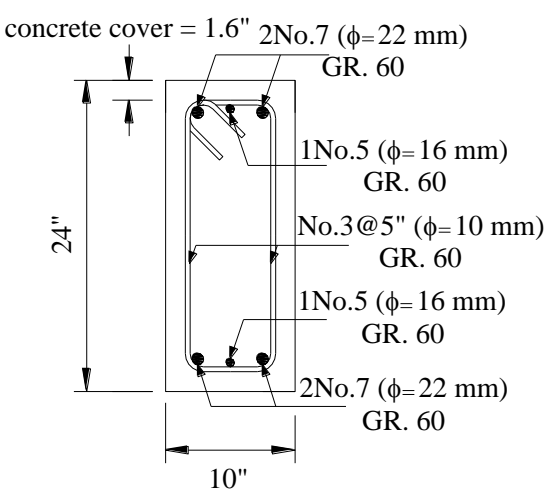

SP 1

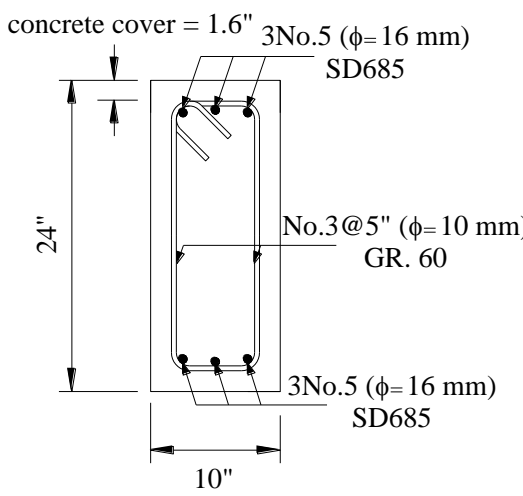

SP 2

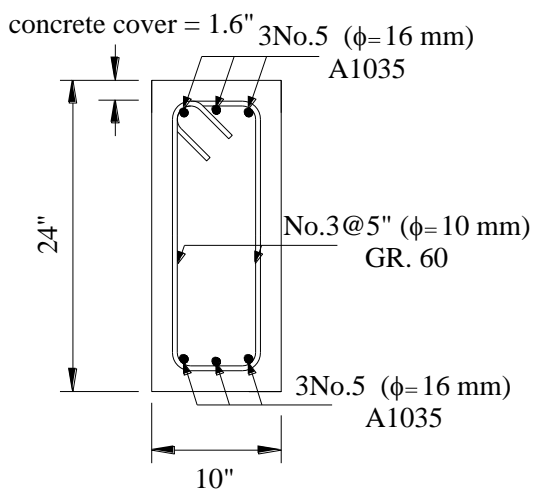

SP 3

(a) Specimens Tested by Cheng and Giduquio ${ }^{22}$ (Note : 1 in. $=25.4 \mathrm{~mm}$ )
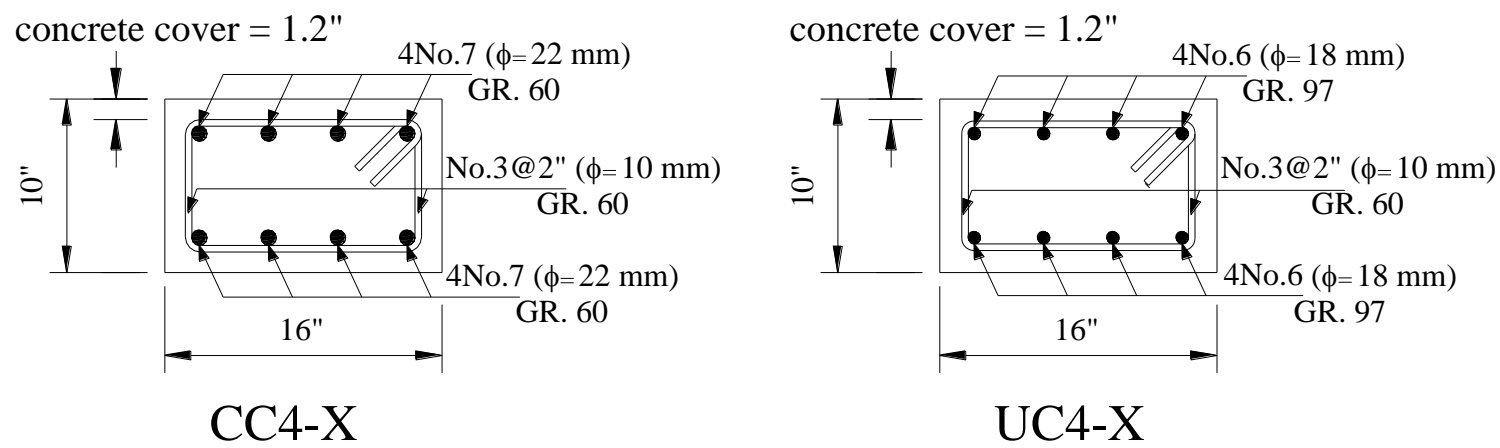

(b) Specimens Tested by Tavallali et al. ${ }^{1}(1$ in. $=25.4 \mathrm{~mm})$

Fig. 5 - Beam Cross-Sections 


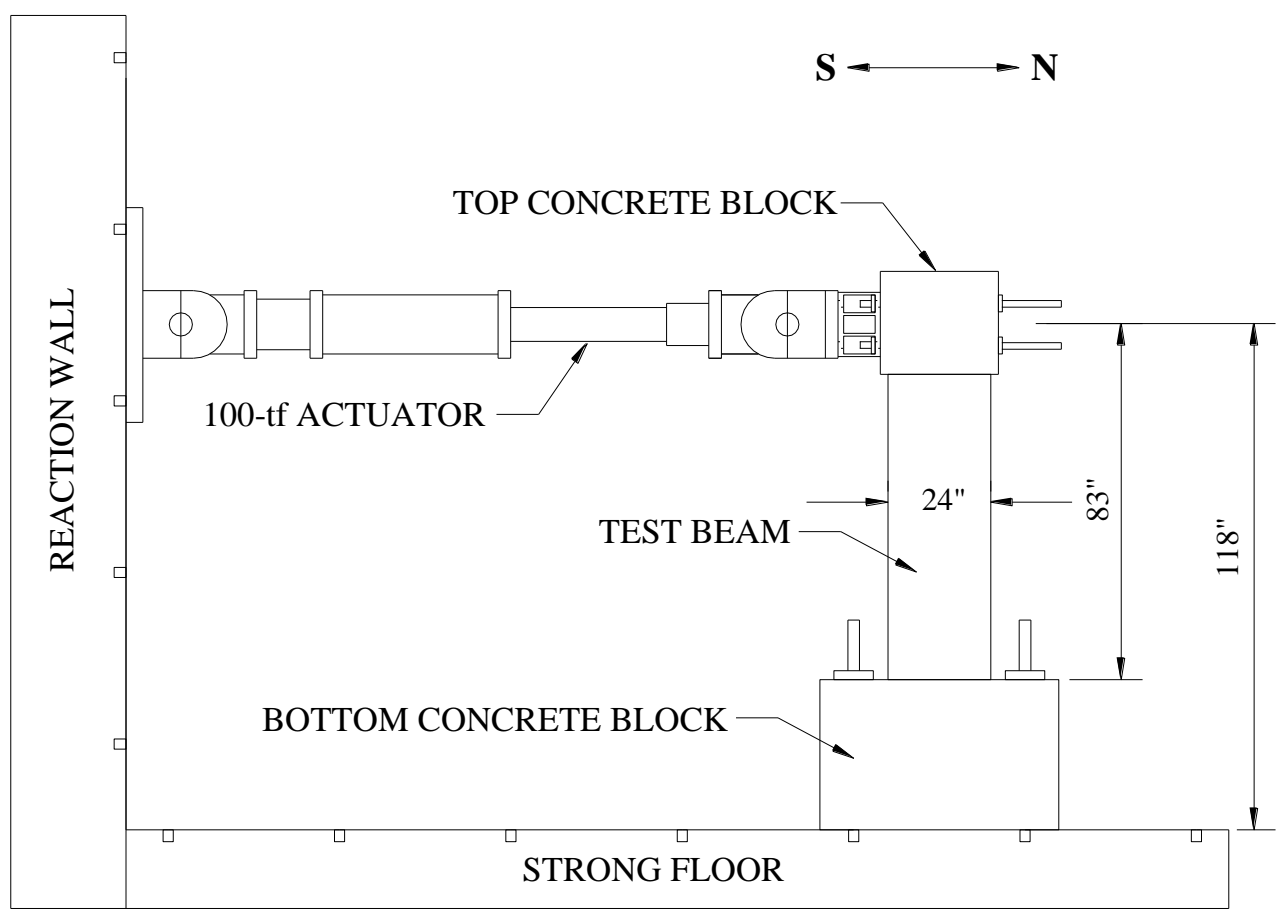

(a) Cheng and Giduquio ${ }^{22}(1$ in. $=25.4$ mm)

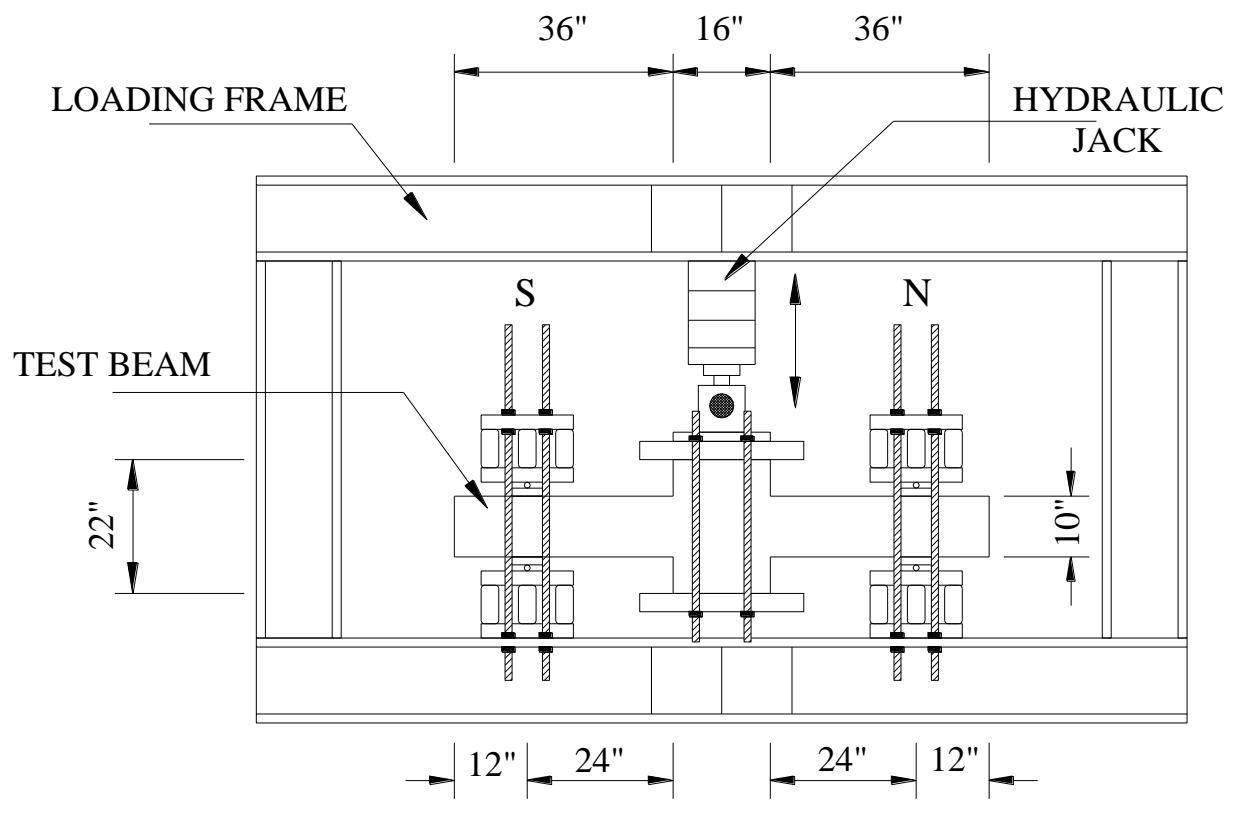

(b) Tavallali et al. ${ }^{1}(1$ in. $=25.4 \mathrm{~mm})$

Fig. 6 - Test Setup 


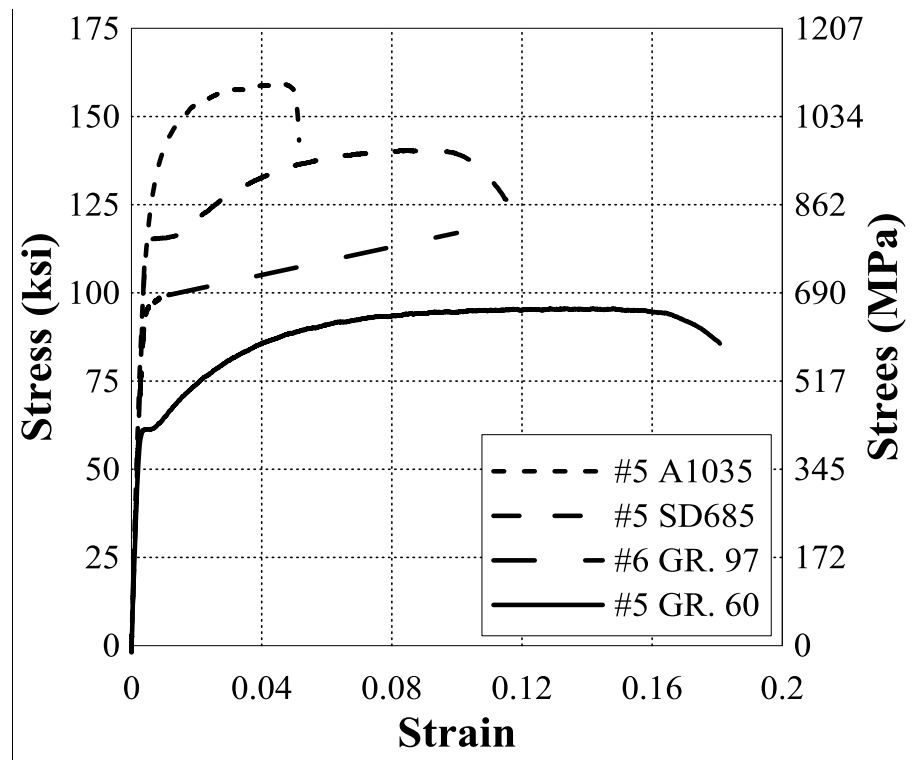

Fig. 7 - Representative Tensile Properties of Different Types of Reinforcing Steels 


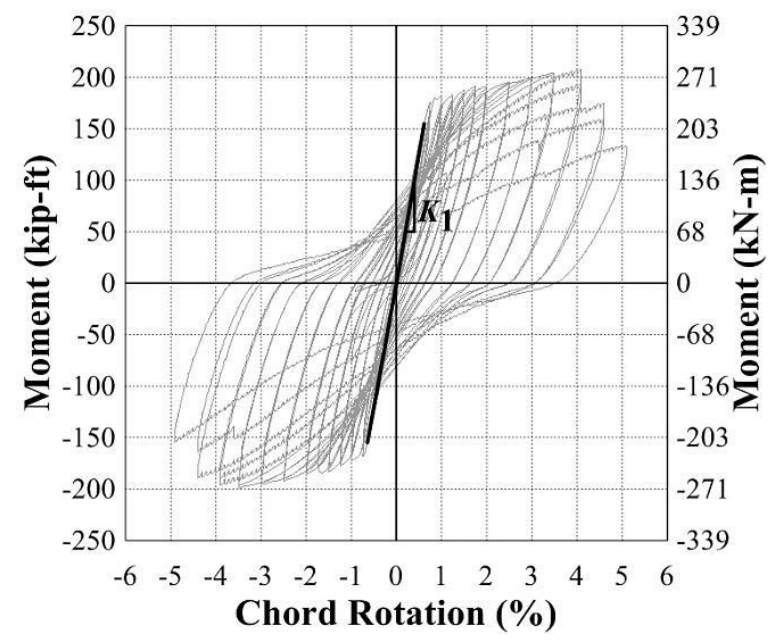

(a) SP1

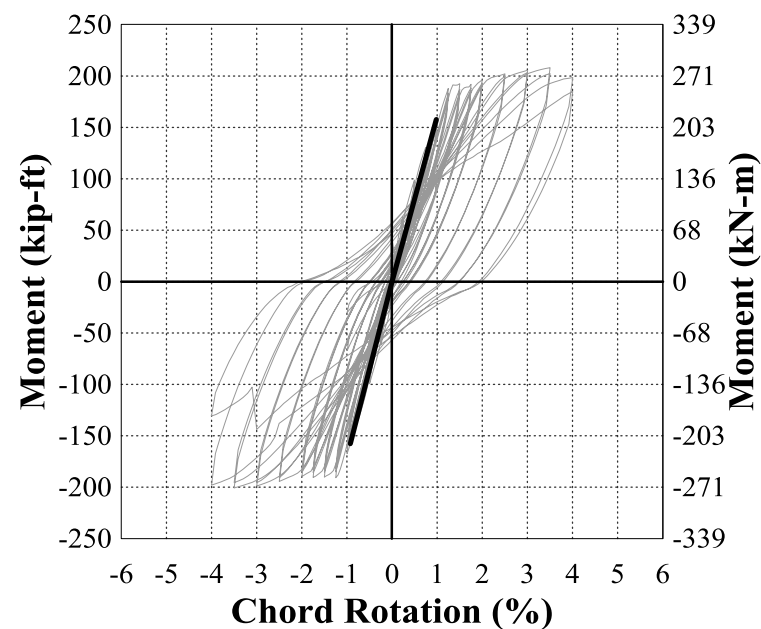

(b) SP2

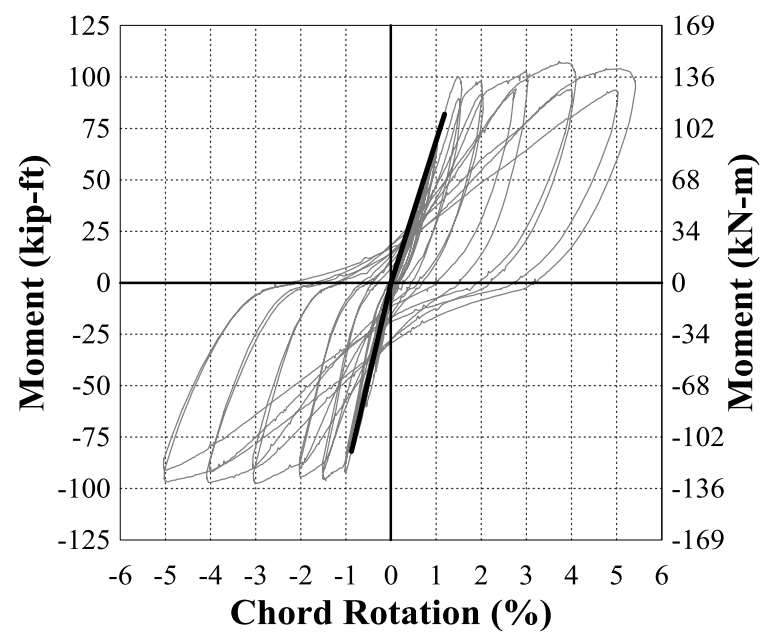

(d) CC4-X North

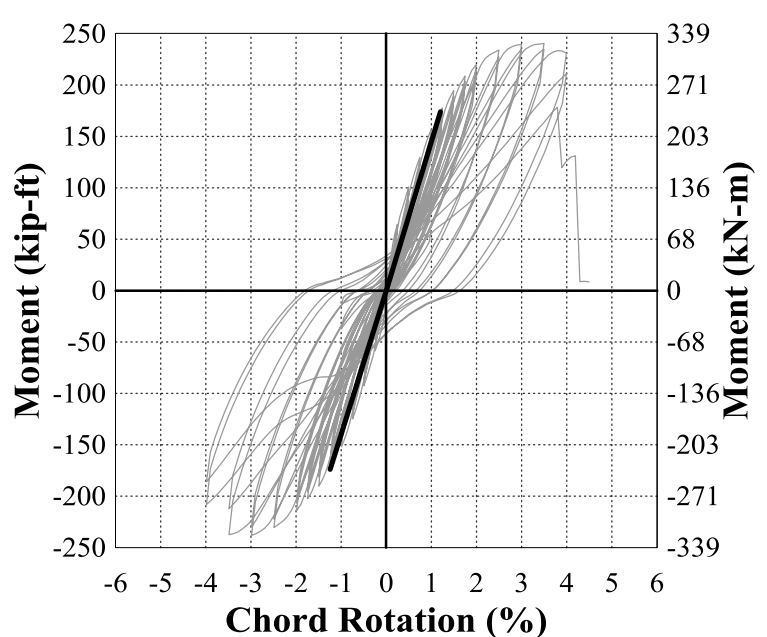

(c) SP3

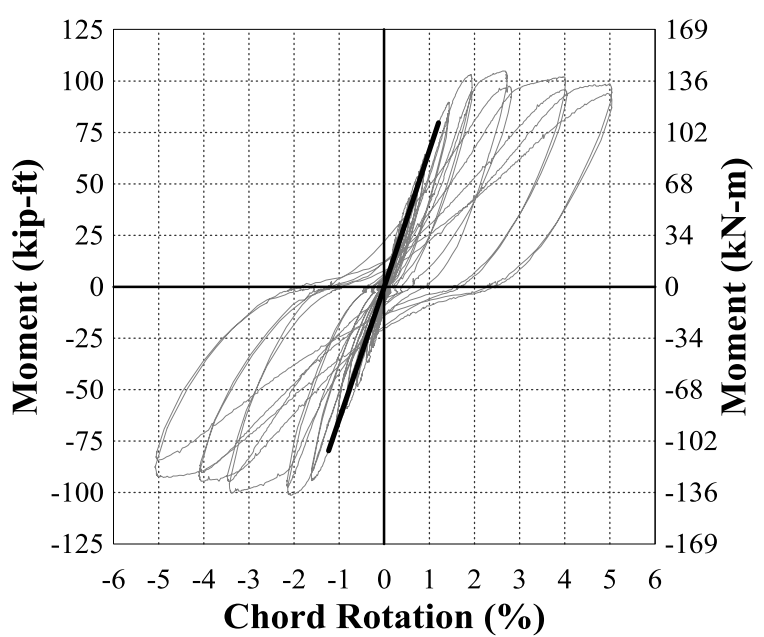

(e) UC4-X South

Fig. 8 - Measured Response for Specimens with Normal and High-Strength Steel 


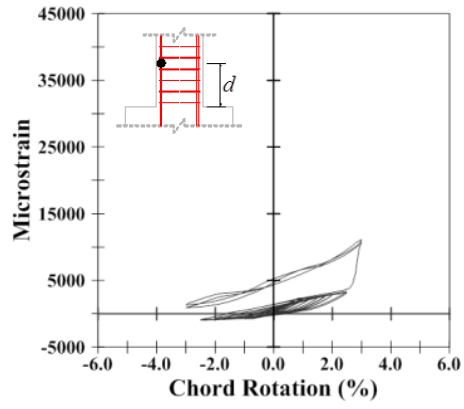

SP 1

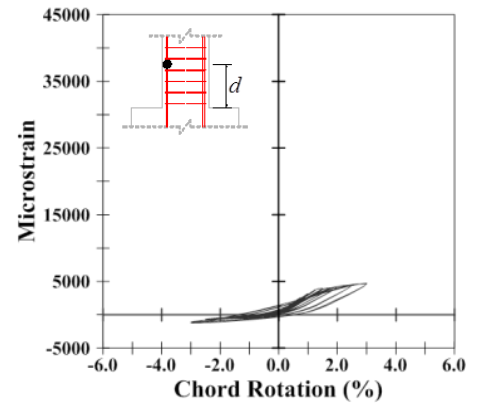

SP 2

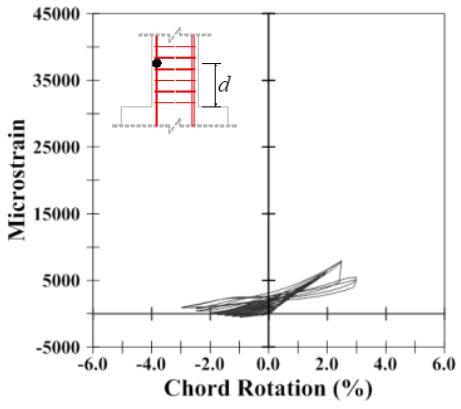

SP 3

(a) Group 1 (Cheng and Giduquio ${ }^{22}$ )

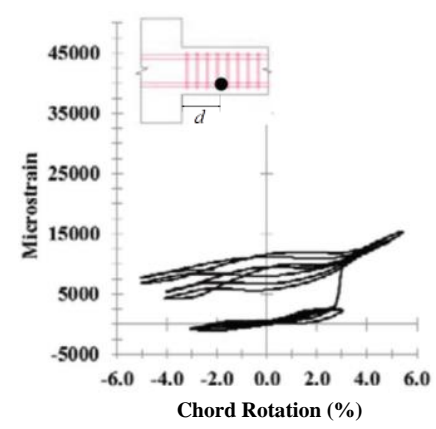

CC4-X

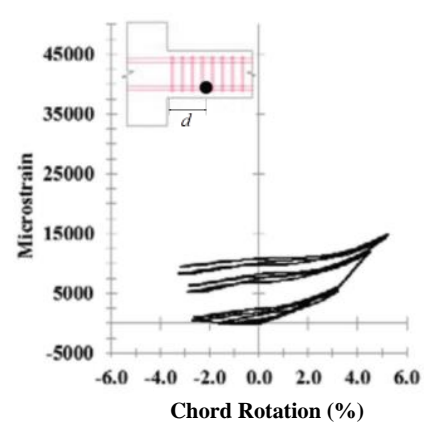

UC4-X

(b) Group 2 (Tavallali et al. ${ }^{1}$ )

Fig. 9 - Strain Gauge Readings for Normal and High-Strength Steel

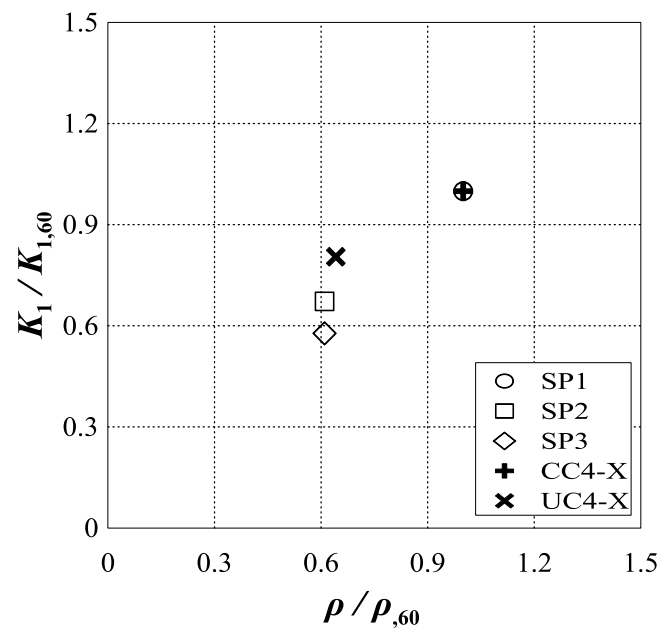

Fig. 10 - Measured Stiffness of Test Specimens 
Table 1 - Summary of Stress Block Models from Committee Reports and Building Codes

\begin{tabular}{|c|c|c|c|c|}
\hline Model & $f_{c}^{\prime(1)}(\mathrm{ksi})$ & $\begin{array}{c}\alpha_{1}^{(2)} \\
\left(f_{c}^{\prime} \text { in ksi) }\right.\end{array}$ & $\begin{array}{c}\beta_{1}^{(3)} \\
\left(f_{c}^{\prime} \text { in } \mathrm{ksi}\right)\end{array}$ & $\varepsilon_{c u}{ }^{(4)}$ \\
\hline $\mathrm{ACI}^{3}$ & All & 0.85 & $\begin{array}{c}0.85, f_{c}^{\prime} \leq 4 \mathrm{ksi} \\
0.85-0.05\left(f_{c}^{\prime}-4\right) \geq 0.65\end{array}$ & 0.0030 \\
\hline ACI ITG-4 ${ }^{4}$ & All & $\begin{array}{c}0.85, f_{c}^{\prime} \leq 8 \mathrm{ksi} \\
0.85-0.015\left(f_{c}^{\prime}-8\right) \geq 0.70\end{array}$ & $\begin{array}{c}0.85, f_{c}^{\prime} \leq 4 \mathrm{ksi} \\
0.85-0.05\left(f_{c}^{\prime}-4\right) \geq 0.65\end{array}$ & 0.0030 \\
\hline $\mathrm{CSA}^{7}$ & $3-12$ & $0.85-0.01 f_{c}^{\prime} \geq 0.67$ & $0.97-0.0172 f_{c}^{\prime} \geq 0.67$ & 0.0035 \\
\hline Eurocode $^{8}$ & $f_{c}^{\prime} \leq 13.05$ & $\begin{array}{c}1.00, f_{c}^{\prime} \leq 7.25 \mathrm{ksi} \\
1.00-\left(f_{c}^{\prime}-7.25\right) / 29 \geq 0.80\end{array}$ & $\begin{array}{c}0.8, f_{c}^{\prime} \leq 7.25 \mathrm{ksi} \\
0.8-\left(f_{c}^{\prime}-7.25\right) / 58 \geq 0.70\end{array}$ & $\begin{array}{c}0.0035, f_{c}^{\prime} \leq 7.25 \mathrm{ksi} \\
0.0026+0.035\left[\frac{13.0-f_{c}^{\prime}}{14.5}\right]^{4}\end{array}$ \\
\hline $\mathrm{JSCE}^{9}$ & $f_{c}^{\prime} \leq 11.6$ & $1-0.0207 f_{c}^{\prime} \leq 0.85$ & $0.76-11.6 \varepsilon_{c u}$ & $\begin{array}{c}{\left[\frac{22.5-f_{c}^{\prime}}{4350}\right]} \\
0.0025 \leq \varepsilon_{c u} \leq 0.0035\end{array}$ \\
\hline $\mathrm{NZS}^{10}$ & All & $\begin{array}{c}0.85, f_{c}^{\prime} \leq 8 \mathrm{ksi} \\
0.85-0.0267\left(f_{c}^{\prime}-8\right) \geq 0.75\end{array}$ & $\begin{array}{c}0.85, f_{c}^{\prime} \leq 4.35 \mathrm{ksi} \\
0.85-0.0534\left(f_{c}^{\prime}-4.35\right) \geq 0.65\end{array}$ & 0.003 \\
\hline
\end{tabular}

(1) $f_{c}^{\prime} \quad=$ specified compressive strength of concrete

(2) $\alpha_{1}=$ ratio between the stress of the rectangular block and the maximum stress

(3) $\beta_{1}=$ factor relating depth of equivalent rectangular compressive stress block to neutral axis depth

(4) $\varepsilon_{c u}=$ maximum usable strain at extreme concrete compression fiber

Table 2 - Summary of Stress Block Models from Researchers

\begin{tabular}{|c|c|c|c|c|}
\hline Model & $f_{c}^{\prime}(\mathrm{ksi})$ & $\begin{array}{c}\alpha_{1} \\
\left(f_{c}^{\prime} \text { in ksi) }\right.\end{array}$ & $\begin{array}{c}\beta_{1} \\
\left(f_{c}^{\prime} \text { in ksi }\right)\end{array}$ & $\varepsilon_{c u}$ \\
\hline $\begin{array}{l}\text { Azizinamini } \\
\text { et al. }{ }^{11}\end{array}$ & $f_{c}^{\prime} \leq 15^{*}$ & $\begin{array}{c}0.85, f_{c}^{\prime} \leq 10 \mathrm{ksi} \\
0.85-0.05\left(f_{c}^{\prime}-10\right) \geq 0.60\end{array}$ & $\begin{array}{c}0.85, f_{c}^{\prime} \leq 4 \mathrm{ksi} \\
0.85-0.05\left(f_{c}^{\prime}-4\right) \geq 0.65\end{array}$ & 0.0030 \\
\hline Bae and Bayrak ${ }^{12}$ & $f_{c}^{\prime} \leq 20^{*}$ & $\begin{array}{c}0.85, f_{c}^{\prime} \leq 10 \mathrm{ksi} \\
0.85-0.0276\left(f_{c}^{\prime}-10\right) \geq 0.67\end{array}$ & $\begin{array}{c}0.85, f_{c}^{\prime} \leq 4.4 \mathrm{ksi} \\
0.85-0.0276\left(f_{c}^{\prime}-4.4\right) \geq 0.67\end{array}$ & $\begin{array}{l}0.0030, f_{c}^{\prime} \leq 8 \mathrm{ksi} \\
0.0025, f_{c}^{\prime}>8 \mathrm{ksi}\end{array}$ \\
\hline $\begin{array}{l}\text { Ibrahim and } \\
\text { MacGregor }^{13}\end{array}$ & $f_{c}^{\prime} \leq 20^{*}$ & $0.85-0.0086 f_{c}^{\prime} \geq 0.725$ & $0.95-0.0172 f_{c}^{\prime} \geq 0.70$ & 0.0030 \\
\hline $\begin{array}{l}\text { Khadiranaikar and } \\
\text { Awati }^{14}\end{array}$ & $f_{c}^{\prime} \leq 17.4$ & $\begin{array}{c}0.85, f_{c}^{\prime} \leq 2.9 \mathrm{ksi} \\
0.85-0.0069\left(f_{c}^{\prime}-2.9\right) \geq 0.75\end{array}$ & $\begin{array}{c}0.85, f_{c}^{\prime} \leq 2.9 \mathrm{ksi} \\
0.85-0.0138\left(f_{c}^{\prime}-2.9\right) \geq 0.67\end{array}$ & 0.0030 \\
\hline Mertol et al. ${ }^{15}$ & $f_{c}^{\prime} \leq 18$ & $\begin{array}{c}0.85, f_{c}^{\prime} \leq 10 \mathrm{ksi} \\
0.85-0.02\left(f_{c}^{\prime}-10\right) \geq 0.75\end{array}$ & $\begin{array}{c}0.85, f_{c}^{\prime} \leq 4 \mathrm{ksi} \\
0.85-0.05\left(f_{c}^{\prime}-4\right) \geq 0.65\end{array}$ & 0.0030 \\
\hline $\begin{array}{l}\text { Ozbakkaloglu and } \\
\text { Saatcioglu }^{16}\end{array}$ & $f_{c}^{\prime} \leq 19$ & $\begin{array}{c}0.85, f_{c}^{\prime} \leq 4 \mathrm{ksi} \\
0.85-0.01\left(f_{c}^{\prime}-4\right) \geq 0.72\end{array}$ & $\begin{array}{c}0.85, f_{c}^{\prime} \leq 4 \mathrm{ksi} \\
0.85-0.013\left(f_{c}^{\prime}-4\right) \geq 0.67\end{array}$ & 0.0030 \\
\hline
\end{tabular}

*Limits are based on the collected database

Note: for notation, see footnotes in Table 1. 
Table 3 - Required Tensile-Test Properties of High-Strength Steel

\begin{tabular}{|c|c|c|c|c|c|}
\hline Bar Type & Bar Size & $\begin{array}{l}\text { Min. } \varepsilon_{s h}{ }^{(1)} \\
\quad(\%)\end{array}$ & $\begin{array}{c}\operatorname{Min} . \varepsilon_{s u}{ }^{(2)} \\
(\%)\end{array}$ & $\begin{array}{c}\text { Min. } f_{y}^{(3)} \\
\text { ksi } \\
(\mathrm{MPa})\end{array}$ & $\begin{array}{c}\text { Min. } f_{u}^{(4)} \\
\text { ksi } \\
(\mathrm{MPa})\end{array}$ \\
\hline $\mathrm{SD} 65^{23}$ & All Size & 1.4 & 10 & $\begin{array}{c}99 \text { to } 110 \\
\text { (685 to } 755)\end{array}$ & $>1.25 f_{y}$ \\
\hline $\mathrm{SD}_{785^{23}}$ & Less than No. 4 & NA & 8 & $\begin{array}{c}114 \\
(785) \\
\end{array}$ & $\begin{array}{c}135 \\
(930) \\
\end{array}$ \\
\hline \multirow{2}{*}{$\begin{array}{c}\text { Grade } 100 \\
\text { A } 1035^{24}\end{array}$} & $\begin{array}{l}\text { No. } 3 \text { to } \\
\text { No. } 11\end{array}$ & \multirow{2}{*}{ NA } & 7 & \multirow{2}{*}{$\begin{array}{l}100^{(3)} \\
(690)\end{array}$} & \multirow{2}{*}{$\begin{array}{c}150 \\
(1030)\end{array}$} \\
\hline & No. 14 , No. 18 & & 6 & & \\
\hline Grade $97^{25}$ & Less than No. 6 & NA & 9 & $\begin{array}{c}97 \\
(670) \\
\end{array}$ & $\begin{array}{c}116 \\
(800) \\
\end{array}$ \\
\hline
\end{tabular}

(1) $\varepsilon_{s h}=$ strain at onset of strain hardening

(2) $\varepsilon_{s u}=$ total fracture elongation, measured within an 8 -in. (203 mm) gauge length

(3) $f_{y}=$ yield strength determined using the $0.2 \%$-offset method.

(4) $f_{u}=$ tensile strength

Table 4 - Summary of Longitudinal Reinforcement Properties

\begin{tabular}{|c|c|c|c|c|c|c|}
\hline Bar Type & Bar Size & $f_{y, \text { test }}{ }^{(1)}, \mathrm{ksi}(\mathrm{MPa})$ & $f_{u, t e s t}, \mathrm{ksi}(\mathrm{MPa})$ & $\begin{array}{c}\varepsilon_{s u, \text { test }}{ }^{(2)} \\
(\%)\end{array}$ & $\begin{array}{c}f_{u, \text { test }} / \\
f_{y, \text { test }}\end{array}$ & $E_{s h}{ }^{(3)}$, $\mathrm{ksi}(\mathrm{MPa})$ \\
\hline $\begin{array}{c}\text { Grade } 60 \\
\text { SP1 }\end{array}$ & No. 5 & $61(420)$ & $95(654)$ & 18 & 1.56 & 265 (1830) \\
\hline $\begin{array}{c}\text { Grade } 60 \\
\text { SP1 }\end{array}$ & No. 7 & $70(482)$ & $99(682)$ & 19 & 1.41 & 203 (1400) \\
\hline $\begin{array}{c}\text { SD685 } \\
\text { SP2 }\end{array}$ & No. 5 & $115(792)$ & $140(965)$ & 12 & 1.23 & $320(2210)$ \\
\hline $\begin{array}{c}\text { A1035 } \\
\text { SP3 }\end{array}$ & No. 5 & $127(875)$ & 159 (1096) & 6 & 1.26 & $804(5540)$ \\
\hline $\begin{array}{c}\text { Grade } 60 \\
\text { CC4-X }\end{array}$ & No. 7 & $65(448)$ & $98(675)$ & 16 & 1.51 & $212(1460)$ \\
\hline $\begin{array}{c}\text { Grade } 97 \\
\text { UC4-X }\end{array}$ & No. $6^{(4)}$ & 97 (668) & $117(806)$ & 10 & 1.21 & 193 (1330) \\
\hline
\end{tabular}

For notation see Table 3

(1) Determined using $0.2 \%$ offset method.

(2) Measured within an 8-in. (203 $\mathrm{mm}$ ) gauge length.

(3) The secant modulus between the point where yielding initiates and the point at peak on the steel stress-strain curve.

(4) Actual bar diameter is 0.71 in. $(18 \mathrm{~mm})$. 
Table 5 - Summary of Test Results

\begin{tabular}{|c|c|c|c|c|c|}
\hline Specimen & SP1 & SP2 & SP3 & CC4-X & UC4-X \\
\hline $\begin{array}{c}f_{c}^{\prime} \\
\text { ksi (MPa) }\end{array}$ & $5.4(37)$ & $5.4(37)$ & $5.5(38)$ & $6.0(41)$ & $6.2(43)$ \\
\hline $\begin{array}{c}\text { Drift } d_{u}{ }^{(1)} \\
(\%)\end{array}$ & 4.7 & 4.0 & 4.0 & 5.2 & 5.0 \\
\hline $\begin{array}{c}M_{\text {peak }}{ }^{(2)} \\
\text { kip-ft }(\mathrm{kN}-\mathrm{m})\end{array}$ & $204(276)$ & $205(277)$ & $240(324)$ & 103(139) & 103(139) \\
\hline $\begin{array}{c}{\frac{V_{\text {peak }}}{b d \sqrt{f_{c}^{\prime}}}}^{(3)} \\
\text { psi }(\mathrm{MPa})\end{array}$ & $1.93(0.16)$ & $1.93(0.16)$ & $2.25(0.19)$ & $5.20(0.43)$ & $5.10(0.42)$ \\
\hline $\begin{array}{c}M_{n, e}{ }^{(4)} \\
\text { kip-ft }(\mathrm{kN}-\mathrm{m})\end{array}$ & $173(235)$ & $177(239)$ & $195(264)$ & $91(123)$ & $89(120)$ \\
\hline$\frac{M_{\text {peak }}}{M_{n, e}}$ & 1.18 & 1.16 & 1.23 & 1.13 & 1.16 \\
\hline$\varepsilon_{t}^{(5)}$ & 0.0217 & 0.0206 & 0.0191 & 0.0078 & 0.0079 \\
\hline
\end{tabular}

(1) $d_{u}=$ the average maximum chord rotation in each loading direction prior to a $20 \%$ decrease in strength.

(2) $M_{\text {peak }}=$ the average peak flexural strength in each loading direction.

(3) $V_{\text {peak }}=$ the average peak shear strength in each loading direction; $b=$ width of test specimens and $d=$ effective depth of test specimens.

(4) $M_{n, e}=$ the expected flexural strength evaluated using equivalent concrete stress block based on current code ${ }^{3}$ and bilinear steel stress-strain curve using $f_{y}$ with tested material properties.

(5) $\varepsilon_{t}=$ tensile longitudinal strain associated with $M_{n, e}$. 